\title{
SLS/BIALL Academic Law Library Survey 2012/2013
}

\section{David Gee}

Deputy Librarian and Academic Services Manager

Institute of Advanced Legal Studies, School of Advanced Study, University of London

By-line This is the latest report analysing the results of the Society of Legal Scholars and BIALL Survey. It has been written by David Gee, Deputy Librarian at the Institute of Advanced Legal Studies, School of Advanced Study, University of London

\section{Summary of key findings}

- $\quad$ The response rate was $83.78 \%$; very good, and near the record of $85.4 \%$ (section 3);

- $\quad$ There was an increase in the number of old and new universities enrolling $\mathrm{PhD}$ and MPhil students (section 5);

- $11 \%$ of respondents failed to meet the SLS Statement of Standards 3.1 on space and physical facilities, through not housing all relevant collections in one place (section 6);

- $\quad$ The three most popular law databases in terms of number of subscriptions continued to be Westlaw UK, LexisßLibrary and HeinOnline. But there was still some fluidity in the range of subscriptions held, for $10 \%$ of respondents were considering cancelling a subscription to an electronic source before the end of July 2014 whilst $18 \%$ were considering a new subscription before the same date (section 7);

- $\quad$ JSTOR was again the most widely used general database in law libraries (section 8);

- $\quad$ The most popular free website with legal content which assists teaching staff and students in their law studies and which they access frequently was BAILII or the British and Irish Legal Information Institute at www.bailii.org/ which is based at the Institute of Advanced Legal Studies (section 9);

- Ex Libris (offering products such as Aleph, Voyager and Alma) was the most popular supplier of library management systems to academic law libraries in the UK and Ireland (section 10);

- Mean expenditure increased by $6 \%$ across all respondents on the level in 2012 . Old universities reported a $2.5 \%$ increase in mean expenditure on 2012 , whilst new universities reported a substantial 14.7\% increase in mean expenditure on 2012 (section 11.1);

- Mean expenditure on law materials per student in old universities was $£ 218$ (down $8.8 \%$ on 2012) whereas in new universities it was $£ 246$ (a 9.8\% increase on 2012). This indicates that mean spend per student at new universities has overtaken mean spend per student at old universities for the first time (section 11.1);

- The proportion of total law material expenditure on monographs remained steady at $21 \%$, serials were down to its lowest ever at $46 \%$ and databases were up again at $33 \%$ (section 11);

- Separate results on overall expenditure on law library materials in institutions not providing vocational or professional award courses are provided (section 11.7);

- The highest proportion of income to fund the acquisition of law materials continued to come from general library funds (section 12); 
- $61 \%$ of all law schools made no contribution to funding the acquisition of law materials, a higher percentage than in past years. Moreover, of those law schools that did contribute, they appeared to do so less generously with the average amount contributed by law schools overall decreasing by $22 \%$ (although there was a wide variation between the contributions provided by old and new universities) (section $12)$;

- A slightly lower percentage of responding libraries did not have any library staff which spent $50 \%$ or more of their working time on the care and servicing of the law collection. Several explained that their activities were being diluted into library-wide responsibilities or the law collection was being serviced from a team of staff with wider subject duties (section 13);

- Overall average staffing numbers slightly increased in both old and new universities (section 13);

- $90 \%$ of respondents had at least one member of law library staff who had a LIS qualification, although for 21 institutions this was less than one full-time member of staff (section 13.4);

- As found in previous surveys, library staff with law qualifications were much more common in old universities (section 13.4);

- Law librarians in almost all responding institutions continued to be involved in providing legal research skills training. Most often it was in partnership with law school lecturers and in over half of the institutions in a programme involving free external trainers supplied by the major database providers (section 14.1);

- Librarians were involved in training for all types of course though not all their contributions were integrated with the law teaching curriculum (section 14.3);

- In general, the amount of teaching received by a research postgraduate has increased. However, decreases are noted for undergraduates, postgraduate vocational course students and taught course postgraduates (section 14.4);

- On most measures librarians in both old and new universities appear to be spending more time teaching than previously (section 14.5);

- As in the five previous surveys, face-to-face contact through IT or database workshops is still the most popular delivery method (section 14.6);

- The overall number of institutions integrating information literacy principles within the law undergraduate programme increased (section 14.7);

- A minority of responding institutions had links with overseas institutions and a wide variety of types of support were reported, ranging from email support to overseas students in finding resources to the purchase and shipping out of new print materials (section 15);

- The most popular other activities in both old and new universities are firstly creating web subject and research guides, followed by providing content for law library web pages, providing content for social networking sites and providing content for web portals or gateways. Writing published articles is the least popular other activity (section 16);

- Comparing other activities in old and new universities, it is more likely that law library staff will be contributing to web subject and research guides, law library web pages, social networking sites and web portals or gateways in old universities. On the other 
hand, it is more likely that law library staff will be writing published articles in new universities (section 16).

The following report outlines the activities and funding of academic law libraries in the UK and Ireland in the academic year 2012/2013. The figures have been taken from the results of a survey questionnaire undertaken by Academic Services staff at the Institute of Advanced Legal Studies on behalf of the British and Irish Association of Law Librarians (BIALL).

This survey has been run on an annual basis since 1996 and reported in The Law Librarian and latterly in Legal Information Management. It is sponsored either by the British and Irish Association of Law Librarians (BIALL) or by the Society of Legal Scholars (SLS).

I shall attempt to draw comparisons with previous surveys where helpful. In particular "2012" refers to the 2011/2012 data (Gee, 2013), "2011" refers to the 2010/2011 data (Gee, 2012) and "2010" refers to the $2009 / 2010$ data (Clinch, 2011). All the previous surveys referred to are referenced at the end of the report.

\section{$2 \quad$ Methodology}

The survey methodology was improved this year, conveniently making an electronic editable PDF form version of the survey questionnaire available for the first time. In January 2014 an email containing both a link to the survey questionnaire on the IALS website and an attached editable PDF form was dispatched to 111 institutions in the UK and Ireland. Respondents could therefore complete the electronic questionnaire at one sitting, save it under the name of their institution and email it back to us. Alternatively they could print out the questionnaire to work on over a period of time and then complete the electronic version, save it and email it back to us. We were also still happy to receive completed paper versions of the survey questionnaire by post if this was the method preferred by individual respondents.

As in the past research centres with no students or only small numbers of postgraduates where the main university law library was invited to respond to the survey, were excluded. For similar reasons, the Oxbridge college libraries were excluded but, as usual, responses from the Bodleian and Squire law libraries were invited.

This year's survey is funded by the British and Irish Association of Law Librarians (BIALL). A copy of the questionnaire is available on the IALS website at:

http://ials.sas.ac.uk/library/SLS BIALL survey.htm

\section{Response rates}

This year 93 forms were returned representing a response rate of $83.78 \%$, a slight increase on last year's $82.88 \%$ and close to the record of $85.4 \%$, set in $2003 / 2004$. I am very grateful to all those law librarians who took the time to respond. A complete list of the academic law libraries that returned a completed 2012/2013 survey questionnaire is contained in the Appendix. I am not usually made aware of the reasons for non-returns, but this year I was told that three libraries were recruiting a new law librarian in early 2014 and this explained why they did not return a completed questionnaire. A key reason for delayed returns was that law librarians are finding it more difficult to extract relevant data from the central university. On our part we try to be very flexible and have permitted some respondents to take up to eight weeks after the initial deadline to send in a promised reply.

Another response rate of over $80 \%$ is very welcome and should permit the presentation of a reasonably accurate picture of academic law libraries in the UK and Ireland. 
To help detect patterns in law library provision, the data has been analysed, as in previous years, by type of institution:

- "old" universities incorporated before 1992

- "new" universities incorporated in or after 1992

- institutes of higher education and other types of institution

Forty-three old universities responded (49 last year), as did 47 new universities (41 last year) and 3 other institutions (2 last year). The response profile has changed slightly, with six fewer results for old universities and a six more results from new universities. This may affect comparisons with past results.

\section{$4 \quad$ Definitions}

In many of the following sections, the survey responses are analysed using range, mean and median.

- The range indicates the smallest and the greatest value of the responses and helps us understand the diversity of responses.

- The mean has been calculated by adding up all the responses and dividing by the number of responses to get an "average". The mean can be distorted by one or two responses which are very large or very small.

- The median is the mid point and is calculated through ordering the responses by size from the smallest to the greatest and finding the middle response. There will be an equal number of responses below the median and above the median and so it provides a benchmark of what a "typical" university is doing.

All percentages from this point onwards have been rounded to the nearest whole number.

\section{$5 \quad$ Student numbers}

A representation of the number of law students served by the libraries helps in understanding the framework in which provision is made and can assist librarians in comparing their provision with institutions of similar sizes.

Respondents were asked to indicate the total number of taught course students (bodies, not FTEs) in the Law School enrolled on exempting undergraduate law degrees or professional or academic postgraduate courses in law. Eighty-nine out of the total of 93 respondents gave figures for student numbers, ranging from 47 to 7,000 (66 to 7,046 in 2012). The median number of law students was 676 (712 in 2012). The mean number was 876 (827 in 2012).

Respondents in old universities reported student numbers between 47 and 1,835 (66 to 2,038 last year), with a mean of 844 ( 825 last year) and a median of 860 (855 last year). In new universities, the range was 71 to 7,000 (75 to 7,046 last year), with a mean of 957 (860 last year) and a median of 572 (540 last year). Among the three other institutions, the range was 90 to 220 (130 to 290 in 2012). The mean was 142 (210 in 2012) and the median was 117 (210 in 2012).

Some movements are evident in the number of students attending responding institutions in $2012 / 2013$ as compared with the previous year. The mean amongst old universities is slightly higher whilst the same measure for new universities is very much higher. This could be partly due to the slightly changed survey response profile.

Ninety two or $99 \%$ of respondents (98 or $96 \%$ in 2012) offered an exempting undergraduate law degree. Thirty one or 33\% of respondents (30 or 33\% in 2012) hosted the Legal Practice Course (LPC), Bar Vocational Course (BVC), Diploma in Legal Practice (Scotland), Professional Practice Course (Ireland) or Degree of Barrister-at-law (Ireland). This represents $21 \%$ of old university respondents, $47 \%$ of new universities and $0 \%$ of other institutions. 
Twenty two or $24 \%$ ( 28 or $30 \%$ in 2012 ) of respondents provided courses leading to other law professional awards, such as the Common Professional Examination or Institute of Legal Executives qualification. Twelve percent of old universities, 34\% of new universities and $33 \%$ of other institutions ran such courses. The final category was for other taught courses, such as LLM, which led to a postgraduate award in law. Eighty six or $93 \%$ (85 or $92 \%$ in 2012) of institutions ran these postgraduate courses, including $100 \%$ of old and $89 \%$ of new universities and $33 \%$ other institutions. The movements in the percentages of respondents offering particular courses this year, as compared with last year, are relatively small and could be explained by the slightly changed survey response profile.

Respondents also indicated whether the law school enrolled students onto research courses, such as those leading to $\mathrm{PhD}$ and MPhil. Seventy four or $80 \%$ (71 or $77 \%$ in 2012) of institutions indicated that they did. One hundred percent of old universities, $66 \%$ of new universities and $0 \%$ of other institutions had such students. Research students were not included in the count of law students detailed above. The percentage for old universities has increased to $100 \%$ again, and the trend is up for the new universities $(61 \%$ in 2012$)$.

\section{$6 \quad$ Location of the law library}

Respondents were asked to indicate, from a list, which most closely matched the circumstances in their institution.

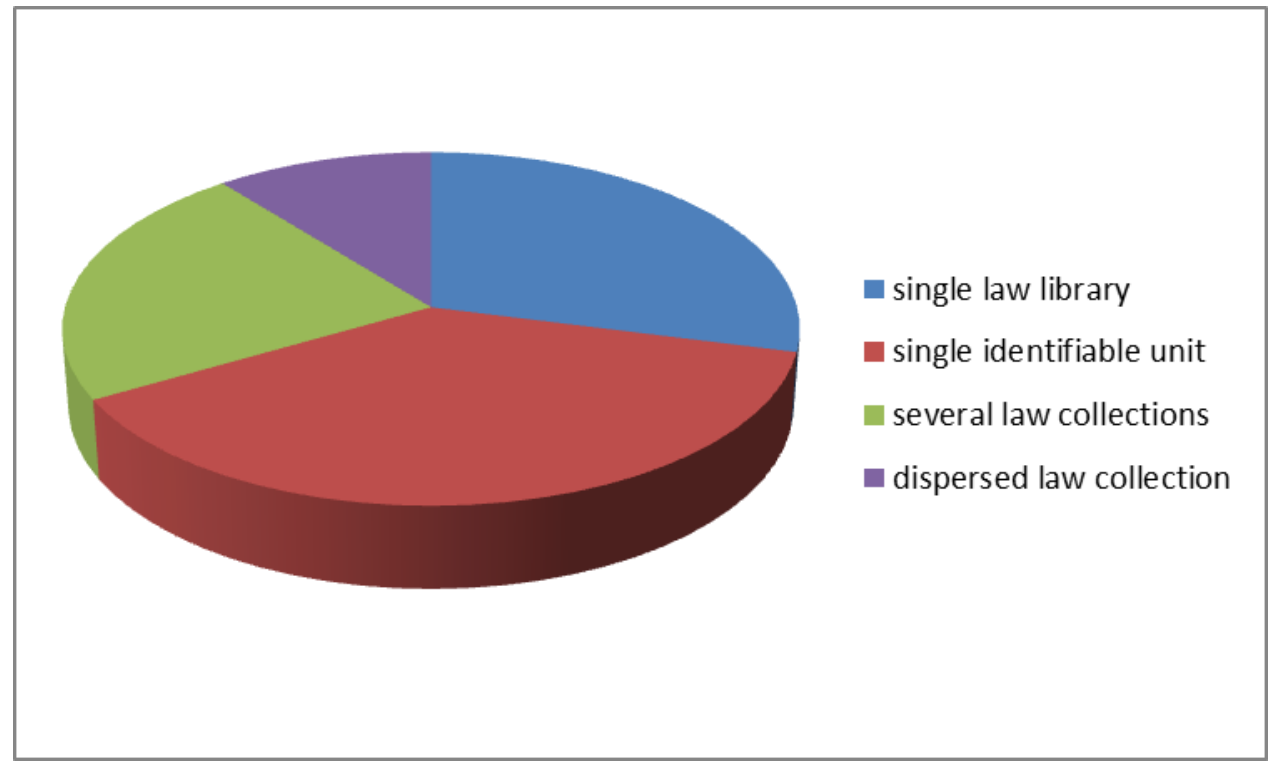

Graph 1: Location of the law library

As the above pie chart demonstrates, across all respondents:

- $29 \%$ had a single law library in a location separated from other subject collections ( $34 \%$ in 2012). Of these, there were 17 (2012: 21) old universities, 9 (2012: 9) new and 1 (2012: 1) other institution.

- $38 \%$ had a law collection not so separated but shelved so as to form a single identifiable unit (34\% in 2012). These included 16 (2012: 17) old universities, 17 (2012: 13) new and 2 (2012: 1) other institutions.

- $22 \%$ had several law collections each in a different location ( $20 \%$ in 2012$)$. These included 6 (2012: 7) old, 15 (2012: 12) new universities and 0 (2012: 0) other institutions.

- $11 \%$ had a law collection dispersed wholly or partly among other subject collections $(12 \%$ in 2012). Of these, 4 (2012: 4) were old universities, 6 (2012: 7) were new universities and 0 (2012: 0$)$ other institutions. 
Forty percent (2012: $43 \%$ ) of old universities responding had a single and separate law library, while $19 \%$ (2012: $22 \%$ ) of new universities and $33 \%$ (2012: $50 \%)$ of other institutions had a single and separate law library.

Thirty seven percent (2012: $35 \%$ ) of old universities described their law collection as being shelved so as to form a single identifiable unit but not separate from other collections. Thirty six percent (2012: $32 \%$ ) of new universities described their law collection in a similar way, and $66 \%$ (2012: $50 \%)$ of other responding institutions.

Nine percent (2012: $8 \%$ ) of old universities had several law collections, each in a different location, but $13 \%(2012: 29 \%)$ of new universities and no other institutions $(0 \%)$ reported several collections (2012: 0\%).

As in past surveys, the main reason for more than one law collection was the establishment of a separate library targeted at vocational course students, such as those on the LPC or BVC, in addition to a main law collection.

The comments to the SLS Statement of Standards 3.1 (Society of Legal Scholars, 2009) on space and physical facilities require "the housing of all relevant collections ... as a unified whole in one place ...". This year the figures suggest that this criterion was not met by at least the $11 \%$ of institutions reporting dispersed collections.

Nine percent of old universities, $13 \%$ of new universities and $0 \%$ of other institutions had law collections wholly or partly dispersed among other subject collections. Last year the figure was $12 \%$ overall: in detail, in $2012,8 \%$ of old, $29 \%$ of new and $0 \%$ of other institutions had dispersed collections.

Although the overall percentage trend of dispersed collections is down very slightly by $1 \%$ on 2012 which is encouraging, one must remember that the general response profile for different types of institution has altered a little between last year's and this year's surveys, so the actual institutions responding are slightly different and are probably partly the reason for the downward changes noted.

\section{$7 \quad$ Legal Databases}

Contrary to the rest of the questionnaire, respondents were asked to indicate their legal database subscriptions at the present time, rather than in the academic year 2012/2013. The results below therefore show the position in February 2014.

As in recent years, all respondents gave details of subscription databases used in connection with the teaching and research work of the law school. The ten most frequently mentioned law databases are displayed in the graph below. 


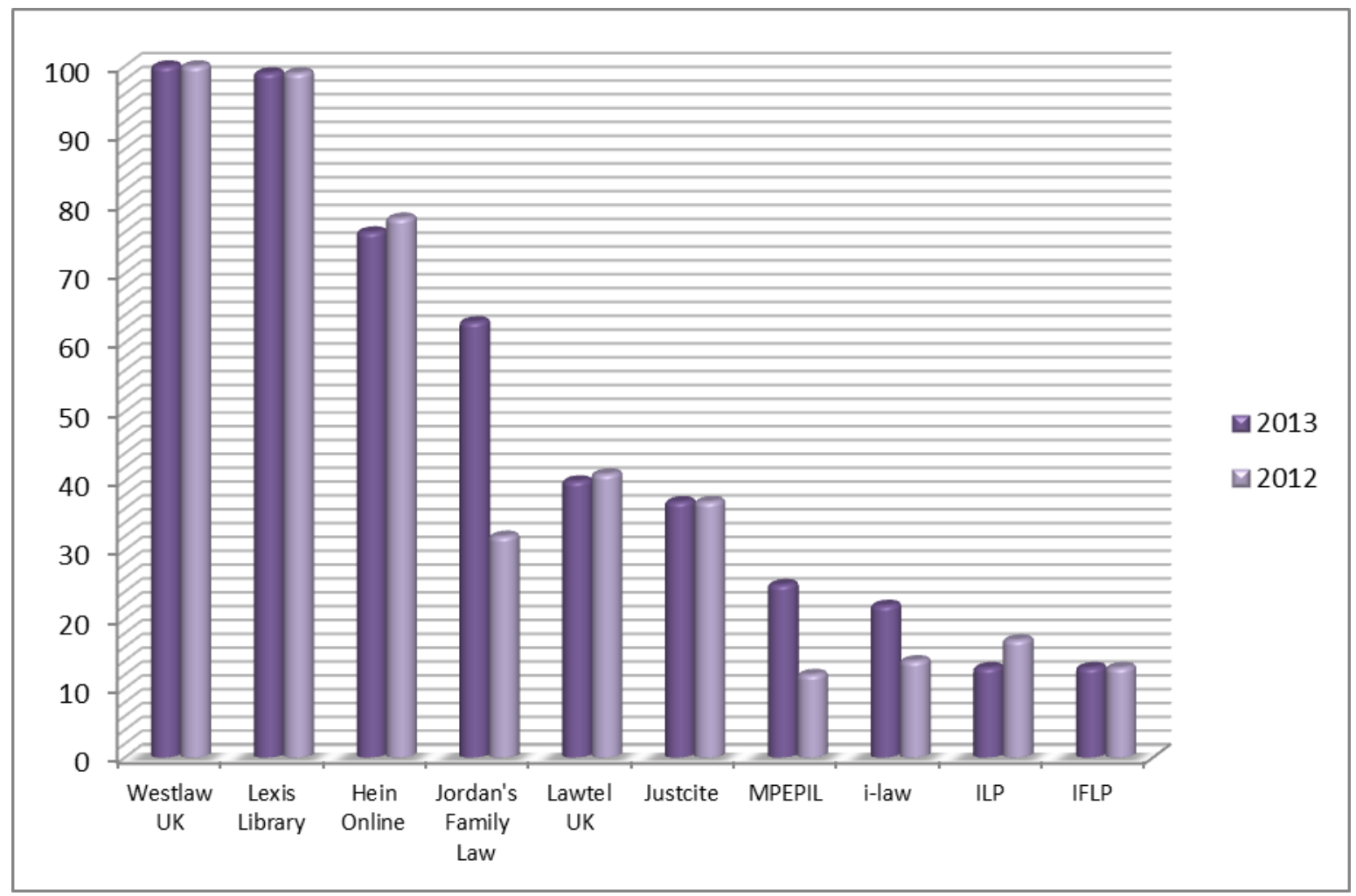

Graph 2: Top 10 legal databases

The law databases' academic market is still fluid but much less than several years ago and generally similar to last year. On a positive note, $18 \%$ of respondents $(11 \%$ last year and $17 \%$ the year before) were planning new subscriptions before the end of July 2014 . However on the negative side, $10 \%$ ( $7 \%$ last year and $19 \%$ the year before) noted planned or recent cancellations before the financial year end.

Like last year, a small number of law databases continue to dominate the market. Westlaw UK was taken by every respondent (100\%) and Lexis ${ }^{\circledR}$ Library was taken by all bar one $(99 \%$ of respondents). Last year Westlaw UK was also taken by all respondents $(100 \%)$ and Lexis $\AA$ Library was also taken by all bar one (99\%). HeinOnline, kept the third position it first gained in 2007 with a slightly reduced percentage, being taken by 70 or $75 \%$ of respondents (last year: 78\%). Jordan's Family Law Online increased its rating to fourth place with 63\% (a marked increase on the $32 \%$ last year).

Of the other databases mentioned by respondents, Lawtel UK dropped very slightly by $1 \%$ to fifth place with 37 or $40 \%$ of respondents taking the database (38 or $41 \%$ last year) and Justcite also dropped one place to sixth place but maintained its percentage with $37 \%$ of respondents ( $37 \%$ last year). The Max Planck Encyclopedia of Public International Law moved up to seventh place with a marked increase to $25 \%$ of respondents (joint tenth place last year with $12 \%$ ) and i-law also did well by maintaining eighth place with an increased percentage of $22 \%$ of respondents (14\% last year). ILP dropped to joint ninth place with $13 \%$ of respondents (seventh place with $17 \%$ last year), whilst IFLP maintained the same ninth place as last year and with exactly the same percentage of respondents rating of $13 \%$.

Looking at the returns for Westlaw in more detail, no respondents were planning to cancel subscriptions and one respondent reported plans to extend their coverage of subscriptions in the year to July 2014 to subscribe to Westlaw IE. Two others noted plans to subscribe to Westlaw China, two mentioned plans to subscribe to Westlaw "Common law library" and four mentioned plans to subscribe to Westlaw e-books.

Sixty two respondents or $67 \%$ subscribed to Westlaw International and all of them also subscribed to Westlaw UK. Seven respondents (2012: 6) subscribed to Westlaw IE (Irish 
Law). Four were based in the Irish Republic and three in the UK, all seven also subscribed to Westlaw UK.

Respondents were asked to indicate the subscriptions they took to particular parts of the Lexis $\AA$ Library product. No respondents reported that they were planning to cancel any part of their existing Lexis $\circledast$ Library subscriptions and one respondent reported plans to subscribe to The Encyclopaedia of Forms and Precedents in electronic format on Lexis.

The Journals module continued to be the most popular product, taken by $94 \%$ of respondents (2012: 98\%). The UK legislation module and the UK cases module were the second most popular, both taken by $93 \%$ of respondents. Halsbury's Laws was the next most popular being taken by $84 \%$ of respondents (please note that the finding relating to Halsbury's Laws in last year's survey report should be ignored as this finding had more to do with a one-off change in the design of the 2013 survey questionnaire rather than being a true reflection of the wide popularity of Halsbury's Laws). The next most popular product was UK newspapers on Lexis at $70 \%$ (2012: $72 \%$ ), whilst the International Materials module was taken by $69 \%$ of respondents. The Encyclopaedia of Forms and Precedents in electronic format was again taken by $54 \%$ (2012: $54 \%)$.

No other Lexis ${ }^{\circledR}$ Library product was taken by more than $10 \%$ of respondents. The next most popular was PSL at 9\% of respondents (2012: 10\%), followed by Employment Law at 8\% (2012: $9 \%$ ). The following databases were taken by $2 \%$ of respondents each: Accountancy lite, Atkins Court Forms (2012: $2 \%$ ), Company and Commercial (2012: 3\%), Immigration and Human Rights (2012: $2 \%)$, IP, and Tax (2012: $2 \%)$. 17 other Lexis®Library databases were mentioned by a total of just over $17 \%$ of respondents.

Two respondents subscribed to LexisNexis $\AA^{\circledR}$ Juris Classeur and one respondent took Lexis Middle East Law as standalone products.

HeinOnline retained its third position with a slightly reduced percentage, being taken by 70 or $75 \%$ of respondents (last year: $78 \%$ ). No respondents reported that they were planning to cancel their Hein subscription and two respondents reported plans to subscribe.

Jordan's Family Law Online increased its rating to fourth place with 59 respondents or $63 \%$ (a marked increase on the $32 \%$ last year).

Lawtel UK took fifth place with $40 \%$ of respondents taking the database ( $41 \%$ last year). Four respondents reported plans to cancel their Lawtel UK subscription, no reasons were given.

Justcite took sixth place and maintained its percentage with $37 \%$ of respondents (37\% last year). Three respondents were hoping to subscribe to a Justcite subscription whilst one respondent was planning to cancel their subscription. Again no reasons were given.

Other than the databases already discussed in detail, the following databases were mentioned by $10 \%$ or more respondents:

$\begin{array}{lrrr} & \begin{array}{r}2014 \\ \text { Institutions }\end{array} & \begin{array}{r}2014 \\ \%\end{array} & 2013 \\ \text { Max Planck Encyclopedia of PIL } & 23 & 25 \% & 12 \% \\ \text { i-law } & 20 & 22 \% & 14 \% \\ \text { Index to Legal Periodicals } & 12 & 13 \% & 17 \% \\ \text { Index to Foreign Legal Periodicals } & 12 & 13 \% & 13 \% \\ \text { Kluwer Arbitration } & 11 & 12 \% & 10 \% \\ \text { PLC Online } & 11 & 12 \% & 9 \% \\ \text { Lawtel EU } & 10 & 11 \% & 12 \%\end{array}$


Databases cited by 3 or more respondents included Oxford Scholarship Online (8 respondents), Oxford Reports on International Law (7 respondents), Beck (5 respondents), Casetrack (5 respondents), WorldTradeLaw.net (5 respondents), "Dalloz" (3 respondents), "ICLR" (3 respondents), "The Making of Modern Law" (3 respondents), OGEL - Oil, Gas and Energy Law (3 respondents).

In total 24 respondents (or 26\%) subscribed to other Justis products other than Justcite. Although not all respondents gave full details of their Justis subscriptions the following information was given: six respondents each subscribed to UK legislation; International Law Reports and Irish Reports. Four respondents subscribed to CELEX and three respondents subscribed to Singapore Law Reports and Session Cases. Two respondents each subscribed to State Trials, English Reports and the Parliament module. One respondent each subscribed to BLISS, England and Wales Reports; Daily Cases; Mental Health Reports and Prison Law Reports.

Databases of European legal information continued to be casualties in the changing academic legal database market. Lawtel EU slightly decreased in popularity and was taken by 10 respondents or $11 \%$ (2012: $12 \%)$. Moreover one respondent planned to cancel Lawtel EU by July 2014. Eurolaw continued to be subscribed to by just 1 respondent or 1\% (2012: 1\%). Only 2 respondents noted a subscription to another full-text EU database.

The median number of legal database subscriptions taken in responding libraries in February 2014 was again 6 (February 2013: 6). The numbers of legal databases offered by institutions ranged from 2 to 46 (2012: 2 to 43 ).

\section{$8 \quad$ Other databases}

In addition to law databases, law schools use a range of more general information databases such as the newspapers which are of relevance to students in a wide range of disciplines. Seventy-eight respondents (84\%) noted other subscription databases which contribute significantly to the teaching and research work of their law school. This showed a small percentage decrease from the $86 \%$ recorded last year.

JSTOR was again the most widely used general database with 60 or $65 \%$ of respondents (2012: 57 or $62 \%$ ). House of Commons Parliamentary Papers (HCPP) was mentioned by 50 or $54 \%$ of respondents (2012: 8 or $9 \%$ ) and gained second place. Third was EBSCO Business Source with 49 or $53 \%$ (2012: 11 or $12 \%$ ) and fourth was ISI Web of Science with 45 or $48 \%$ (2012: 47 or 51\%). Joint fifth was ASSIA and EBSCO academic both with 21 or $23 \%$ (2012: ASSIA was 25 or $27 \%$ and EBSCO academic was 7 or $8 \%$ ). Next was Criminal Justice Abstracts at 19 or $20 \%$ (2012: 22 or $24 \%)$; XpertHR had 6 or $6 \%(2012: 3$ or $3 \%$ ); Public Information Online at 5 or $5 \%(3$ or $3 \%)$ and SCOPUS (abstract and citation database) at 3 or $3 \%$.

By February 2014,54 or $58 \%$ of respondents used a web-based combined newspaper database to access the full range of newspapers (2012: 58 or $63 \%)$. The top three suppliers were again Nexis UK used by 32 respondents (2012: 35), Proquest with 15 respondents (2012: 13) and Factiva with 9 respondents (2012: 8). Gale NewsVault was taken by 4 respondents (2012: 2), and Infotrack and Newsbank were both taken by 3 respondents (2012: Infotrack had 3 and Newsbank had 5). FBIS daily reports had one respondent.

No other newspaper databases were mentioned. The results for this year indicate the continued popularity for Nexis UK with increased numbers for Proquest. Otherwise the results show only slight changes in the subscriber newspaper databases used to contribute significantly to teaching and research in the law school.

\section{$9 \quad$ Most popular free websites with legal content}


For the first time we asked respondents to list, to the best of their knowledge, the names of up to three free websites / databases with legal content which assist teaching staff and students in their law studies and which they access frequently. General search engines such as Google were excluded. The ten most frequently mentioned free websites / databases with legal content are displayed in the graph below.

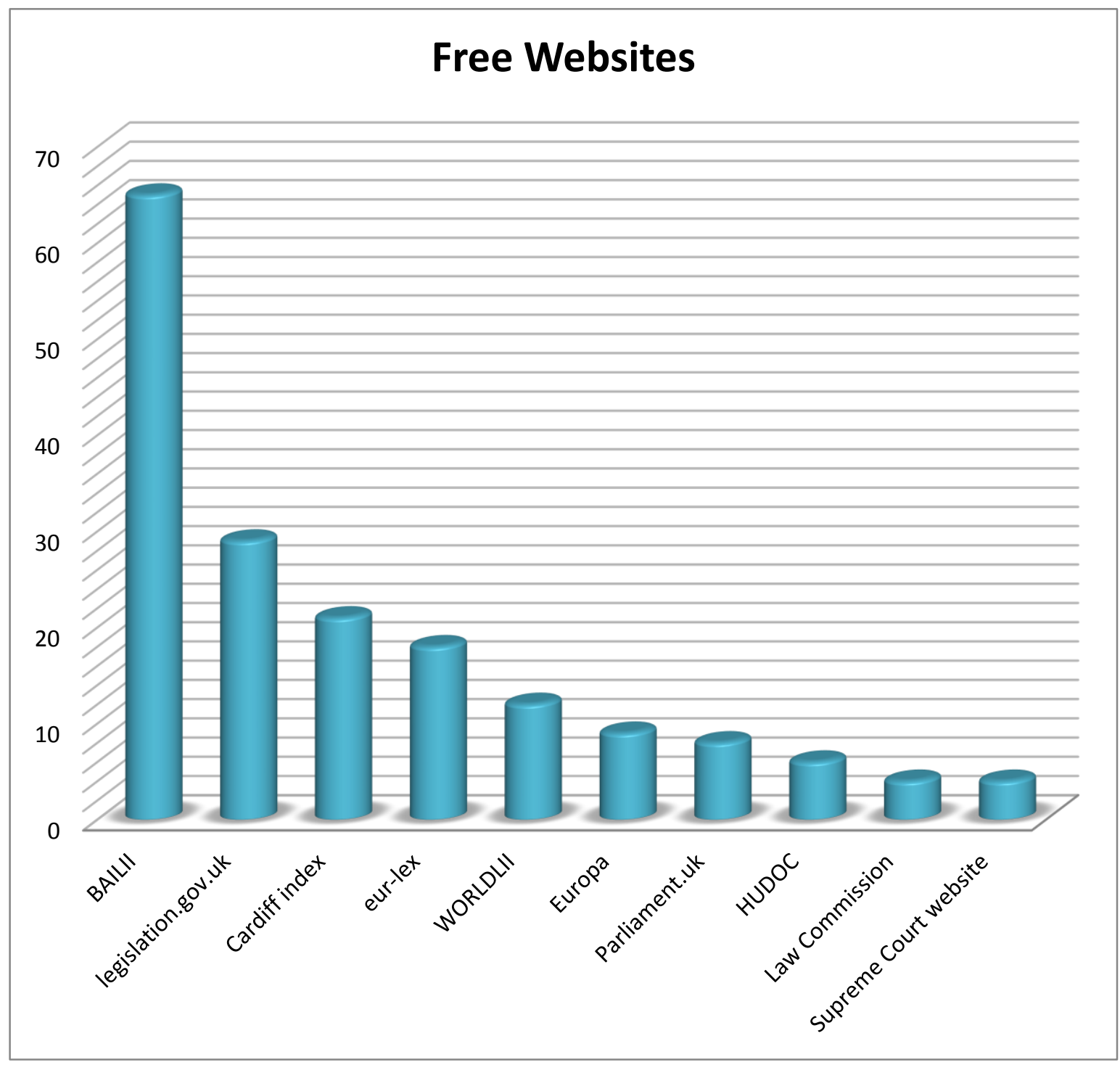

Graph 3: Top 10 free websites / databases with legal content

Eighty four or $90 \%$ of respondents provided this information, although not all respondents listed three sites. The top ten sites are listed below in descending order of popularity:

1. BAILII or the British and Irish Legal Information Institute at www.bailii.org/ which is based at the Institute of Advanced Legal Studies in London.

[65 or $70 \%$ of respondents]

\section{2. www.legislation.gov.uk/}

$$
\text { [29 or 31\%] }
$$

3. Cardiff Index to Legal Abbreviations at www.legalabbrevs.cardiff.ac.uk/ [21 or $23 \%$ ]

4. EUR-Lex at www.eur-lex.europa.eu/

[18 or $19 \%$ ] 
5. WorldLII or World Legal Information Institute at www.worldlii.org/ [12 or $13 \%]$

6. EUROPA - EU website at www.europa.eu/ [9 or $10 \%]$

7. www.parliament.uk

[8 or $9 \%$ ]

8. HUDOC - European Court of Human Rights at www.hudoc.echr.coe.int [6 or $6 \%$ ]

= 9. The Law Commission at www.lawcommission.justice.gov.uk/ [4 or $4 \%$ ]

$=9$. The Supreme Court at www.supremecourt.uk/ [4 or $4 \%$ ]

10 Most popular library management system suppliers

For the first time we asked respondents to provide us with the supplier and product names of their library management system in order to establish which are the most popular library management system suppliers used by academic law libraries in the UK and Ireland. Ninety three or $100 \%$ of respondents provided this information. All the mentioned systems and suppliers are displayed in the graph below, and Ex Libris (offering products such as Aleph, Voyager and Alma) was the most popular supplier.

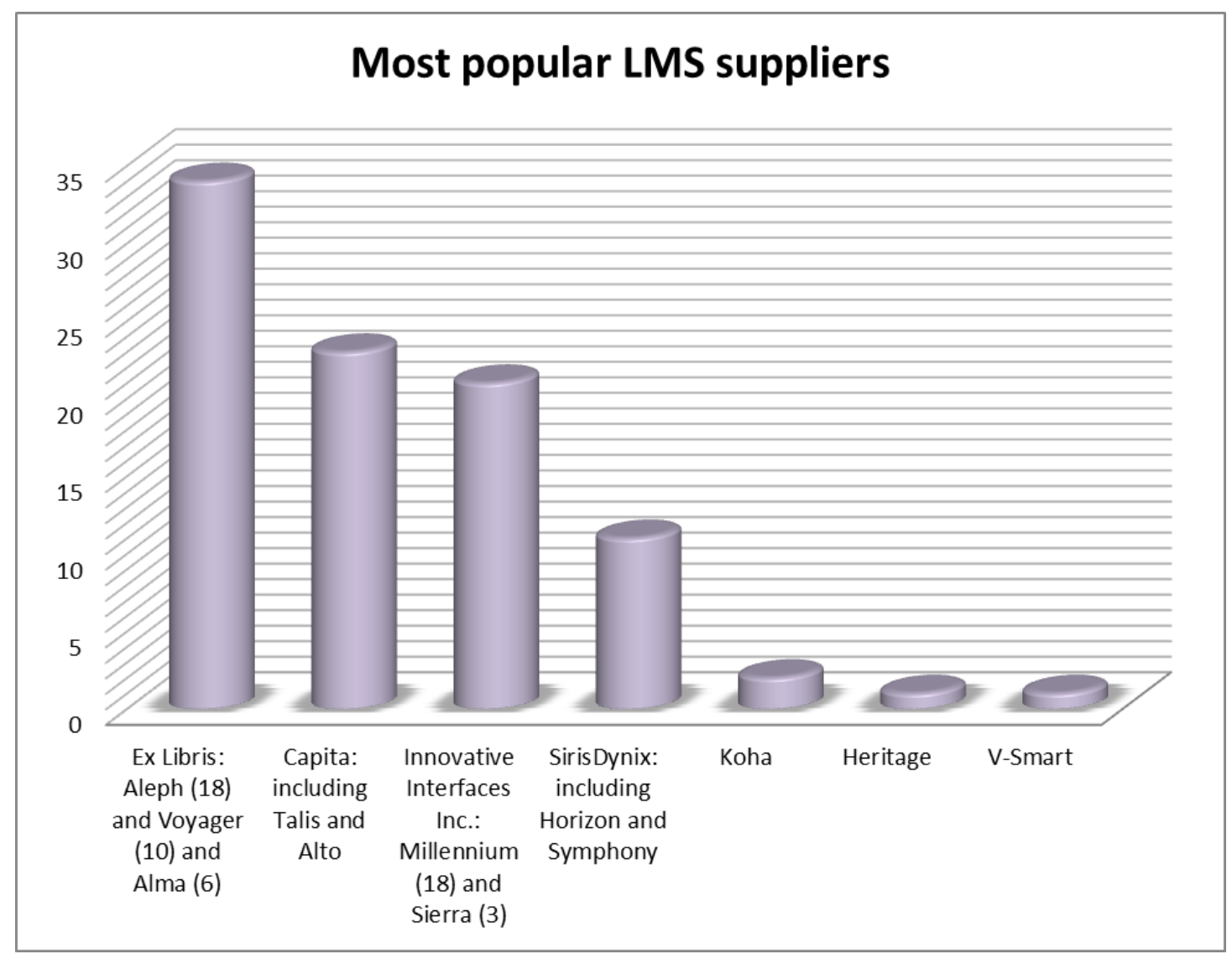

Graph 4: Top library management system suppliers 
The top library management system suppliers are listed below in descending order of popularity:

1. Ex Libris: Aleph (18) and Voyager (10) and Alma (6)

34 respondents

2. Capita: including Talis and Alto

23 respondents

3. Innovative Interfaces Inc.: Millennium (18) and Sierra (3)

21 respondents

4. SirisDynix: including Horizon and Symphony

11 responents

5. Koha

2 respondents

=6. Heritage

1 respondent

=6. V-Smart

1 respondent

Four respondents also mentioned using their library management system alongside the Primo (ExLibris) product for "resource discovery".

\section{Expenditure}

Eight-nine of the 93 respondents were able to provide total expenditure figures for 2012/13. Those respondents who did not respond either could not disaggregate law expenditure from other subjects or were not prepared to provide the information.

\subsection{Total expenditure on law materials}

Total expenditure on the acquisitions of law materials ranged from $£ 14,664$ to $£ 1,705,506$ (2012: $£ 20,160$ to $£ 1,311,000$ ). Mean expenditure was $£ 182,715$ (2012: $£ 172,143)$, a significant 6\% increase on 2012. This marked increase in expenditure in 2012 (following on from a $7 \%$ increase in 2011) is very welcome, although to sound a note of caution the increase may be partly a reflection of the changing pool of survey respondents.

It is helpful in understanding these changes to compare the expenditure in the different types of institution.

Old universities: 42 out of a possible 43 responses (2012: 45 out of 49 ) Range from $£ 36,506$ to $£ 706,500$; median $£ 167,488$ (decreased by $5.2 \%$ on 2012 ); mean $£ 193,479$ (increased by $2.5 \%$ on 2012). $75 \%$ of old universities spent at least $£ 112,881$ (up $5.5 \%$ on last year). $25 \%$ spent more than $£ 230,739$ (down $12.4 \%$ on last year).

New universities: 44 out of a possible 47 responses (2012: 40 out of 41 )

Range $£ 21,433$ to $£ 1,705,506$; median $£ 111,155$ (up $3.7 \%$ on last year); mean $£ 182,621$ (up a $14.7 \%$ on last year which itself was a $30 \%$ increase on the year before). $75 \%$ of new universities spent at least $£ 75,865$ (up $1 \%$ on last year) and $25 \%$ spent more than $£ 176,794$ (down by $13.9 \%$ on last year).

Other institutions: 3 responses (2012: 2)

These figures are not very useful because of the tiny sample. 
These very welcome results seem to indicate that the financial climate is improving on 2012 across the sectors. For both old and new universities the expenditure on law materials results are uniformly positive across all key indicators.

For each law student in a typical university (looking at the median) £198 was spent on law materials. This is a $1.7 \%$ increase on the figure for 2012 .

However, the rate of increase has not been evenly distributed across the higher education sector. In an old university, median spend per student was £201 (2012: £203) but for a student in a new university the median was $£ 193$ (2012: £176), a sharply narrowing gap between old and new universities of just 4\% (2012: 15\%). In other types of institution the median spend per student was £248 (2012: £281). As graph 5 illustrates, the gap between old and new universities fluctuates over time but narrowed in 2012/2013 due to a slight decrease in median expenditure in old universities but a much larger increase in the median for new universities. Per capita expenditure at other types of institution decreased but was still well above old universities. However this marked statistical change is due to the very tiny sample of just 3 respondents.

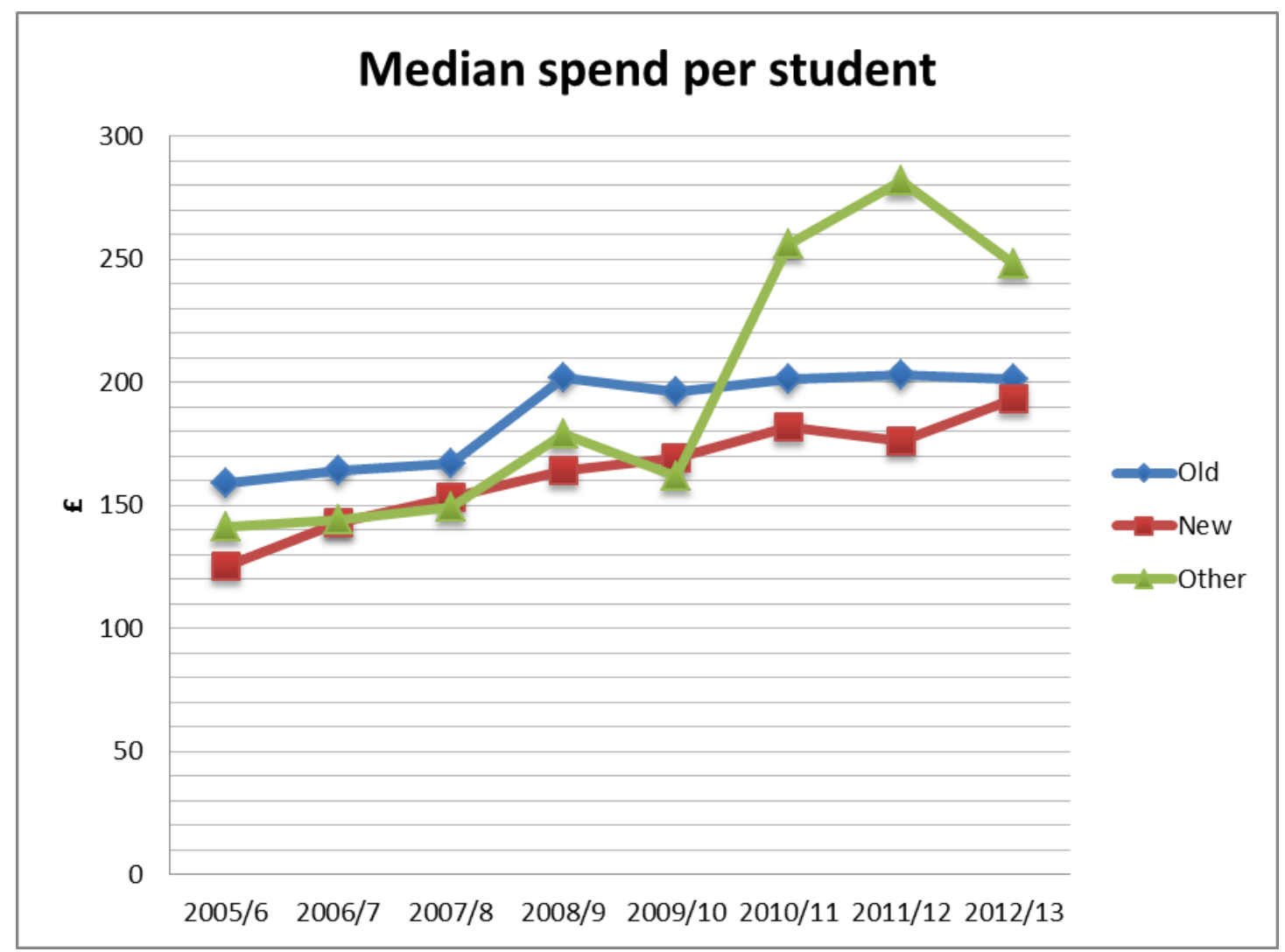

Graph 5: Library materials expenditure per student

Taking the mean, rather than the median, the pattern is also of a sharply narrowing gap between sectors with mean spend per student at new universities overtaking mean spend per student at old universities for the first time. Mean law materials expenditure per student in old universities was $£ 218$, down $8.8 \%$ from 2012 whereas in new universities it was £246, a 9.8\% increase on 2012. In other types of institution the mean spend per student was £220 (2012: £282), indicating a steep decrease, but these results have been calculated over just 3 respondents.

\subsection{Monograph expenditure}


Eighty five respondents provided details of spending on books, three more than last year. Some respondents had difficulty providing a discrete and accurate figure for law expenditure alone owing to the way the university or college budget is divided amongst subject areas.

Expenditure on monographs ranged from $£ 1,848$ to $£ 289,817$ (2012: $£ 895$ to $£ 310,000$ ), with a mean of $£ 36,157$, an increase of $3 \%$ on 2012 and a median of $£ 24,595$ a decrease of $6 \%$ on last year.

In 2013 , on average, monograph acquisitions still accounted for $21 \%$ of total law material expenditure (2012: 21\%; 2011: 21\%; 2010: 22\%). The proportion of total expenditure spent on books ranged from $4 \%$ to $57 \%$ with a median of $18 \%$ (2012: $3 \%$ to $53 \%$, median $20 \%$; 2011: $4 \%$ to $56 \%$, median $19 \%$; 2010 : $6 \%$ to $59 \%$, median $21 \%$ ).

Analysed by type of institution the figures for monograph expenditure were:

Old universities: 40 respondents (2012: 43)

Range $£ 1,848$ to $£ 88,343$; median $£ 29,994$, an increase of $5 \%$ on last year; mean $£ 36,748$ a very small decrease of $0.1 \%$ on 2012 . Mean of $20 \%$ of total law material expenditure (2012: 21\%; 2011: 20\%; 2010: 23\%).

New universities: 43 respondents (2012: 37 )

Range $£ 2,122$ to 2289,817 ; median $£ 20,793$, a decrease of $10 \%$ on last year; mean $£ 34,725$, an increase of $10 \%$ on last year. Mean of $21 \%$ of total law material expenditure (2012: $22 \%$; 2011: $22 \%$; 2010: 21\%).

Other institutions: 2 institutions (2012: 2 )

The range, median and mean figures are not very useful because of the tiny sample. Mean of $27 \%$ of total law material expenditure (2012: $22 \%$ 2011: $16 \%$; $2010: 20 \%)$.

The mean figure for new universities showed a marked increase in expenditure on monographs, whilst the mean figure for old universities showed a very small decrease. The percentage of total law expenditure devoted to monographs has decreased very slightly for both old and new universities. Please note that these figures may be partly a reflection of the changing pool of survey respondents.

\subsection{Serials expenditure}

Eighty five of the 93 respondents who gave any financial figures were able to provide a figure for their spending on serials, three more than last year. The questionnaire defined serials as law journals, statutes, law reports and loose-leaf updates.

As a mean, serials accounted for $46 \%$ of total law materials expenditure, down $3 \%$ on last year and at its lowest level ever (2012: 49\%; 2011: 50\%; 2010: 54\%). The proportion of expenditure given to serials ranged from $6 \%$ to $78 \%$ (2012: $4 \%$ to $81 \% ; 2011: 10 \%$ to $88 \%$; 2010: $13 \%$ to $85 \%$ ) with a median of $50 \%$ (2012: $50 \%$; $2011: 51 \%$; $2010: 57 \%)$. Overall, serials expenditure ranged from $£ 2,274$ to $£ 543,500$ (2012: $£ 2,140$ to $£ 866,000$ ), with a median of $£ 64,249$ (2012: $£ 68,356)$ and a mean of $£ 89,302(2012$ : $£ 95,048)$, the median down by $6 \%$ (2012: up by $19 \%$ ) and the mean down by $6 \%$ (2012: up by $10 \%)$. The percentage falls in both indicators in 2013 are not as much as the increases in 2012.

Analysed by type of institution the figures were:

Old universities: 40 responses (2012: 43)

Range 22,274 to $£ 543,500$; median $£ 87,104$, up $0.1 \%$ on last year; mean $£ 108,156$, up $3.2 \%$ on last year. Mean of 51\% of total law material expenditure (2012: $53 \% ; 2011: 53 \% ; 2010$ : $58 \%)$.

New universities: 43 responses (2012: 37) 
Range $£ 3,713$ to $£ 479,000$; median $£ 47,436$, down $2.7 \%$ on last year; mean $£ 77,153$, down $12 \%$ on last year. Mean of $43 \%$ total law material expenditure (2012: $45 \%$; $2011: 46 \%$; 2010 : $51 \%)$.

Other institutions: 2 responses (2012: 2)

The range, median and mean figures are not very useful because of the tiny sample. Mean of 47\% of total law material expenditure (2012: 39\%; 2011: 46\%; 2010: 43\%).

The percentage of total law expenditure devoted to serials has continued to fall for both old universities. Please note that these figures may be partly a reflection of the changing pool of survey respondents.

\subsection{Database expenditure}

Databases accounted for $33 \%$ of total law materials expenditure in the mean, ranging from $5 \%$ to $89 \%$ and with a median of $30 \%$ (2012: mean of $30 \%$, median of $26 \%$; 2011 : mean of $29 \%$, median of $28 \%$; 2010 : mean of $25 \%$, median of $22 \%$ ). Of the 82 responses (2012: 81 ), expenditure ranged from $£ 6,633$ to $£ 1,072,922$ (2012: $£ 4,391$ to $£ 250,225)$ with a median of $£ 34,320$ (2012: $£ 30,383)$, a rise of $13 \%$ on last year, and a mean of $£ 60,689(2012: £ 44,122)$, a substantial increase on last year's slight decrease.

Analysed by type of institution the figures were:

Old universities: 38 respondents (2012: 42)

Range $£ 14,871$ to $£ 170,000$; median $£ 40,425$, an increase of $15 \%$ on the decrease of $1.5 \%$ last year; mean $£ 54,018$, an increase of $17 \%$ on the decrease of $6.5 \%$ last year. Median $25 \%$ and mean $29 \%$ of total law material expenditure (2012: $22 \%$ and $26 \% ; 2011: 23 \%$ and $28 \%$; 2010: $21 \%$ and $21 \%$ respectively).

New universities: 42 respondents (2012: 37$)$

Range $£ 11,137$ to $£ 1,072,922$; median $£ 32,635$, up $17 \%$ on 2012 ; mean $£ 69,010$ up $60 \%$ on last year. Median 33\% and mean 36\% of total law material expenditure (2012: $30 \%$ and $33 \%$; 2011: $30 \%$ and $33 \%$; 2010: $24 \%$ and $27 \%$ ).

Other institutions: 2 respondents (2012: 2)

The range, median and mean figures are not very useful because of the tiny sample. Median and mean $37 \%$ of total law material expenditure (2012: $39 \%$ and $39 \% ; 2011: 18 \%$ and $29 \%$; 2010: 32\%).

Spending on databases in old universities has increased substantially on the slight decreases of last year, whilst spending on databases in new universities has continued to increase markedly. The percentage of total law expenditure devoted to databases has continued to increase for both old and new universities. Please note that these figures may be partly a reflection of the changing pool of survey respondents.

\subsection{E-book expenditure}

At the suggestion of BIALL for the first time the survey asked respondents to provide expenditure figures on e-books. Twenty eight respondents provided details of spending on ebooks. It is important to point out that more respondents probably purchase e-books, but that they were not all able to provide discrete and accurate figures for this law expenditure alone owing to the way the university or college budget is divided amongst subject areas. As a consequence the following e-book expenditure figures should be treated with some caution, but they are of interest nevertheless.

Expenditure on e-books ranged from $£ 491$ to $£ 23,000$, with a mean of $£ 5,316$ and a median of $£ 3,397$. 
Analysed by type of institution the figures for e-book expenditure were:

Old universities: 13 respondents

Range $£ 1,899$ to $£ 18,000$; mean $£ 5,287$; median $£ 3,500$.

New universities: 14 respondents

Range $£ 491$ to 223,000 ; mean $£ 5,680$; median $£ 3,552$.

Other institutions: 1 institution

The range, median and mean figures are not useful because of the tiny sample.

\subsection{Other expenditure on law materials}

Nineteen respondents noted "other" expenditure, five fewer than last year. Expenditure ranged from $£ 96$ to $£ 48,000$ (2012: $£ 40.23$ to $£ 59,315$ ), with a median of $£ 1,223$ (2012: $£ 2,010)$ a $39 \%$ decrease, and a mean of $£ 4,529(2012$ : $£ 7,147)$ a decrease of $37 \%$.

Six respondents spent the money on inter-library loans, and one a piece on binding, "CLA scanning", digitisation of law materials on reading lists and a membership subscription to BIALL.

\subsection{Expenditure by institutions not providing vocational or professional award courses}

At the suggestion of one respondent we have carried out some analyses on expenditure by only those institutions which offer only an exempting law degree or LLM courses, that is, do not offer vocational courses, such as the LPC, BPTC, Diploma in Legal Practice (Scotland) or Professional Practice Course (Ireland) or Degree of Barrister-at-law (Ireland) or courses leading to professional awards, such as the CPE and CILEx. These institutions believe that vocational courses require the purchase of expensive practitioner materials and so the results given earlier in section 11 are inflated and make comparison with their situation very difficult. So, we have re-run the analyses for total expenditure.

Total expenditure on the acquisition of law materials ranged from $£ 21,433$ to $£ 706,500$ (2012: $£ 20,160$ to $£ 1,311,000)$. Mean expenditure was $£ 155,876$ (2012: $£ 179,304)$, a $13 \%$ decrease on 2012. To sound a note of caution the decrease is probably partly a reflection of the changing pool of survey respondents.

It is helpful in understanding these changes to compare the expenditure in the different types of institution.

Old universities: 31 respondents, 30 provided financial data (2012: 32, 30 provided financial data)

Range £36,506 to £706,500 (2012: $£ 48,057$ to $£ 704,500)$; median £187,332 (2012:

$£ 180,708)$, a $3.7 \%$ increase on last year; mean 2203,611 (2012: $£ 205,165), 0.8 \%$ decrease on last year.

New universities: 20 respondents, 19 providing financial data (2012: 17, 17 provided financial data)

Range $£ 21,433$ to $£ 382,816$ (2012: $£ 20,160$ to $£ 1,311,000)$; median $£ 72,000(2012: £ 75,000)$, decrease of $4 \%$ on 2012 ; mean $£ 87,532$ (2012: $£ 141,391$ ), $38 \%$ decrease on last year.

Other institutions: 1 respondent (2012: 1)

Comparing these results with those in paragraph 11.1 for all respondents, there are differences between the medians and means in old universities, but much more significant differences between the medians and means amongst new universities. The reason for the differences lay in the numbers of students at each institution - those new universities which do 
not offer vocational courses have generally smaller numbers of students than those new universities that do, hence a smaller expenditure on the acquisition of library materials. This distinction is less marked at old universities.

\section{Sources of income}

Eighty eight (2012: 86) respondents gave details of the source of the funds from which law material expenditure was met.

The greatest proportion of acquisitions was funded from general library funds, and all institutions responding received at least part of their income this way. Using the mean, $88 \%$ of old universities', $93 \%$ of new universities' and $100 \%$ of other institutions' income for law library materials was from general library funds $(82 \%, 92 \%$ and $98 \%$ last year). When the median is used the figures are $95 \%, 100 \%$ and $100 \%(2012: 92 \%, 100 \%$ and $99 \%)$. The increase in the mean and median percentages for old universities indicates an increase in focus on general library funds, whilst the slight increase in the mean percentage and the no change in the median percentage for new universities indicates a slight increase or at worse no change in focus on general library funds as the source on last year.

Law schools contributed to funding the acquisition of law materials in 34 institutions (2012: 36 ). As has been noted in previous survey reports, a considerable number of law schools make no such contribution at all (61\% this year, $58 \%$ in $2012,57 \%$ in 2011). On the other hand, $52 \%$ (2012: $48 \%$ ) of old university law schools, $30 \%$ (2012: $38.5 \%)$ of new university law schools and $0 \%$ (2012: $0 \%$ ) of other institutions' schools contributed something.

Of the law schools that contributed, the amount ranged from $£ 1,000$ to $£ 85,330$ (2012: $£ 500$ to $£ 181,000$ ). The median contribution was $£ 17,203$, a decrease of $19 \%$ on last year. The mean was $£ 24,775$, down $22 \%$ on last year.

For the libraries that received funds from the law school, these funds represented a mean of $16 \%$ of the total income for the purchase of law materials, with a median of $11 \%(21 \%$ and $18 \%$ last year). This year the mean percentage contributions by law schools based in old and new universities widened by $7 \%$ with new universities contributing a higher mean percentage than old universities. Of the old university law schools who contributed anything, the mean contribution represented $14 \%$ of the funds for library materials (2012: $21 \%$ ), while new university law schools contributed more at 21\% (2012: 21\%). No 'other' institutions received funds from the law school (2012: 0\%).

In the old universities, median law school funding for law materials was $£ 15,770$, down $35 \%$ on last year. The mean was $£ 21,229$, down by $40 \%$ on last year. In new universities the comparative figures were a median of $£ 21,433$, up by $17 \%$ on last year and a mean of $£ 31,276$, up by $19 \%$ on 2012 .

In summary for law school contributions: well over half of all law schools make no contribution to funding the acquisition of law materials, a higher percentage than in past years. There was an increase in the proportion of old university law schools making a contribution (up $4 \%$ on last year), but there was a $8.5 \%$ fall in the percentage number of new university law schools contributing this year.

In addition, gauged on most indicators, for old universities those law schools which did contribute gave much less than in the past, while in new universities those law schools which did contribute gave much more than in the past. The pattern across the sectors indicated that old universities contributed $14 \%$ to the law library budget whilst new university law schools contributed a higher proportion (21\%) to the law library budget. The mean amount contributed by law schools at old universities decreased by $7 \%$ year on last year, whilst the mean amount contributed by law schools at new universities remained the same as last year. 
Six institutions (2012: 7) reported receiving income from other university budgets for law materials. For these 3 old universities, 3 new universities and 0 other institutions, the amount of income from these sources ranged from $£ 3,500$ to $£ 170,267$ (2012: $£ 1,554$ to $£ 257,770$ ).

One respondent reported funding from user charges (2012: 0).

Finally, 3 institutions (2012: 5) reported receiving financial contributions towards law materials from outside bodies. The sums ranged from $£ 12,000$ to $£ 157,000$ (2012: $£ 6,000$ to $£ 109,705)$, with a median income of $£ 100,000$ (2012: $£ 12,000)$ and a mean income of $£ 89,667$ (2012: $£ 46,755)$. Of these, all three were old universities.

\subsection{Targeted funding from the law school}

Two further questions sought to explore whether law schools paid for specific materials or services.

The first question asked respondents to indicate whether specific types of materials were paid for by the law school. 30 respondents (32\%) replied in the positive (2012: 30,33\%). By far the most frequently mentioned was payment of, or contributions towards, the cost of electronic databases such as Lexis Library, Westlaw or HeinOnline - 15 respondents (2012: 20). Eleven respondents noted that the law school contributed towards the cost of law books, journals or reports (11 in 2012) ranging from research journals to specialist monographs to multiple copies of textbooks. Library materials for the Legal Practice Course or Bar Vocational Course were mentioned specifically by 5 respondents ( 4 in 2012). Contributions to purchasing "postgraduate materials" was mentioned by 1 respondent.

In the second question in this section, respondents were asked to indicate whether the law school contributed to law library expenditure other than for the purchase of law materials.

Seven respondents (8 in 2012) received this additional funding. Five indicated the total amount of the contribution, ranging from $£ 7,600$ to $£ 48,000$ (2012: $£ 1,000$ to $£ 48,000$ ).

Respondents reported receiving funding towards the cost of law librarian staff salaries, CLA costs and digitisation of materials for the VLE.

\section{$13 \quad$ Staffing}

The responses to the questions on staffing provide a picture of the number and qualifications of library staff in academic law libraries. The definition of law library staff provided in the questionnaire was the same as for the previous surveys. To be included in the survey, library staff were to spend $50 \%$ or more of their working time on the care and servicing of the law collection.

Seven (or $8 \%$ ) of the 93 responding institutions had no staff which met this criterion (2012: 8 or $9 \%$ ). Of these, 5 (2012: 4) were old universities and 2 (2012: 4) were new universities. In most instances respondents mentioned that law was just one of a number of subjects for which a team of librarians was responsible, but no one spent the requisite $50 \%$ or more of their time on law alone, or that their responsibilities were diversifying into library-wide activities.

For the 84 respondents (2012: 83) with staff who met the criterion, the full-time equivalent (FTE) number of staff ranged from 0.25 to 24.6 (2012: 0.30 to 23.85) with a median of 1.0 (2012: 1.0$)$ and a mean of 2.75 (2012: 2.53$)$. 34.5\% (2012: 39.8\%) had exactly one FTE member of law library staff.

As in previous surveys, old universities ranged most widely in the number of law library staff and $18.9 \%$ had four or more FTE (2012: $20.4 \%)$, compared to only $11.4 \%$ of new universities (2012: 7.5\%). 
The median for old universities' FTE law library staffing was 1.0 (2012: 1.5) with a mean of 3.25 (2012: 3.15). The median for new universities was 1.0 (2012: 1.0) and the mean was 2.4 (2012: 1.8). The two other institutions were varied in their staffing levels, from 1 to 4 FTE (2012: 1 to 3).

The staffing figures therefore portray a mostly positive picture. The overall mean number of staff increased from 2.53 to $2.75 \mathrm{FTE}$, the mean number of staff for old universities increased from 3.15 to $3.25 \mathrm{FTE}$, and the mean number of staff in new universities increased from 1.8 to 2.4 FTE.

Respondents were asked for the FTE number of staff in professional, clerical and other posts.

\subsection{Professional posts}

Of the 84 institutions which had staff with the care and servicing of the law collections as their sole or principal function, only 2 ( 1 old university and 1 "other" institution) did not have a professional post (2012: 1). Overall, then, of the 84 responding law libraries with staff who met the definition, $97.6 \%$ had a designated professional who could dedicate a significant proportion of their time to the needs of the law service (2012: 99\%). The number of professional FTE posts ranged from 0.25 to 10.9 (2012: 0.25 to 7.50 ) but $48 \%$ of institutions (2012: 57\%; 2011: 64\%) with any professional posts had exactly 1.0 FTE.

In old universities, 15 of the 37 respondents had exactly $1.0 \mathrm{FTE}$, with 13 institutions with less than 1.0 FTE (10 in 2012); 9 had more than 1.0 (10 in 2012) and the maximum was 7.4 FTE professional posts (7.5 in 2012). The mean for old universities was 1.37 FTEs (2012: 1.4 FTEs). The results show a very slight decrease in the level of professional staffing in old universities.

In new universities, 23 of the 44 respondents had exactly 1.0 FTE professional post, with 14 institutions with less than 1.0 FTE (11 in 2012); 7 had more than 1.0 FTE (3 in 2012) and the maximum was 10.9 FTE professional posts. The mean for new universities was 1.35 (2012: 1.2 FTE). These results indicate another slight increase in the level of professional staffing at new universities. In the 3 "other" institutions, one had 0 FTE, one had 1.0 FTE and one had 4.0 FTE (2012: 1 at 1.0 FTE, 1 at 2.0 FTE).

\subsection{Clerical posts}

Turning to clerical posts, 38 institutions out of 84 respondents had clerical staff who met the definition given in section 13 . Of the 46 who had library staff but no clerical staff, 15 were old universities, 29 were new universities and 2 were "other" institutions.

For the 38 institutions that did have clerical staffing, numbers ranged from 0.20 to 18.1 (2012: 0.20 to 16.35 ), with median of 1.0 (2012: 1.0) and a mean of 2.9. Fifty eight percent of old universities reported clerical staff for law as opposed to $34 \%$ of new universities (2012: 62\%, $28 \%)$.

As found in past years, old universities typically had larger numbers of clerical staff. Six of the 21 old universities with clerical staff had four or more such staff and the mean was 3.1 (2012: 2.7), whereas of the 15 new universities with clerical staff only 2 (2012: 1) had four or more such staff.

A partial explanation for the large difference between the presence of clerical staffing in old and new universities could be drawn from the location of the law library. Of the 14 (2012: 12) institutions with more than 2 FTE clerical staff, $7(50 \%)$ had a law library located separately from other collections (2012: $75 \%$ ). Of these 7 institutions, 6 (86\%) were old universities. Where there is a separate law library, staffing is less likely to be shared between subjects, and circulation and other activities will be dedicated to the law collections. It is noteworthy 
however, that $44 \%$ of respondents who had a single law library in a separate location had professional staff but no clerical staffing or "other" staff dedicated to the law service (2012: $39 \%)$.

\subsection{Staff employed in other posts}

Seven institutions (2012: 8) noted law library staff, other than clerical or professional staff, who met the criterion noted in section 13 above. Of these, 4 were old universities and 3 were new universities. FTE numbers of such staff ranged from 0.21 to 1.0 (2012: 0.29 to 1.5). Their duties were specified by three of the seven respondents and included "assistant faculty librarian", "ICT" and "student assistant".

\subsection{Qualifications of staff}

Respondents were asked to indicate how many of the staff whose principal function was the care of the law collections had a professional librarianship or information science (LIS) qualification or an academic or professional qualification in law.

Eight four respondents or $90 \%$ (2012: 83 or $92 \%$ ) of respondents had at least one member of staff who had a LIS qualification, although for 21 institutions this was less than one full-time member of staff (2012: 18).

Forty two (2012: 48) institutions had exactly one FTE member of staff with a LIS qualification and 9 (2012: 7) had three or more FTE staff with such a qualification.

Importantly it is still true to say that there was no unqualified staff in professional posts

Twenty of the 84 respondents representing $21.5 \%$ of institutions (2012: $25.5 \%$ ) had staff with an academic or professional qualification in law. This is a slight decrease in the level seen in most years. Fifteen (2012: 17) had at least one member of staff so qualified, and 12 (2012:

15) had exactly 1.0 FTE staff member with a law qualification.

As found in past surveys, library staff with law qualifications were much more common in old universities. Looking at only those institutions which had any staff which met the criterion noted in section 13 above, in old universities 35\% (2012: 38\%) of law libraries had law qualified staff, compared to new universities where only $16 \%(2012: 17 \%)$ had law qualified staff. None (2012: 0) of the "other" institutions had such staff. Overall, $65 \%$ of the libraries with law qualified staff were in old universities, nine percent lower than last year.

\section{Legal research skills instruction}

User training in law libraries is investigated by this survey every other year. Legal research skills training is defined for the survey in terms of instruction, for example, in how to understand legal abbreviations and in the use of particular law publications or databases. It is not concerned with induction tours, basic introductions to the library or the library catalogue. All 93 (2011: 95) respondents completed this part of the questionnaire this year, and all of them confirmed that they provided some form of legal research skills training.

\subsection{Who provides the instruction?}

In 97\% (2011: 98\%) of institutions law library staff were involved in providing legal research skills training. Only in 1 old and 2 new universities were library staff not involved.

Law School lecturing staff were involved in the training in 73\% (2011: 62\%) of institutions. Other staff, including other professional library staff and IT training officers in the law school, were involved in $6.5 \%(2011: 7 \%)$ of institutions. Several of the database providers offer free 
training to staff and students and so the survey asked whether such external trainers were used for legal research skills instruction. 57\% (2011: 55\%) of respondents' institutions took advantage of such free training. In addition, Lexis or Westlaw student associates contributed to training in $50 \%$ (2011: $49 \%)$ of institutions.

In $9 \%$ (2011: $12 \%)$ of institutions, the law library staff alone provided legal research skills instruction. In a further $16 \%$ (2011: $24 \%)$ of institutions, the law library staff's contribution was supplemented by external trainers or student associates employed by a database supplier. Law Library staff with or without the assistance of external trainers or student associates had sole responsibility for the training in $28 \%$ of old universities, $23 \%$ of new universities and $0 \%$ of other institutions (2011: $31 \%, 42 \%$ and $25 \%$ ).

In $70 \%$ of institutions $(60 \%$ in 2011 ), provision was a joint responsibility between the law library and law school lecturing staff. However, in 60\% (2011: 71\%) of institutions legal research skills instruction also involved other staff or external trainers.

These figures suggest that the law library and law school continue to work together to develop students' legal research skills in a large number of universities and other institutions, aided by free trainers or students associates from the large database providers. Since the last survey two years ago, the use of free external trainers supplied by database providers appears to have increased slightly to $57 \%$, whilst the use of student associates has decreased slightly. The number of law library staff having sole responsibility for legal research skills training has decreased slightly in old universities and more markedly in new universities. The overall picture is still a mix of contributors to legal research skills training in institutions, but with law librarians retaining the key role in the overwhelming majority.

\subsection{For which courses is instruction provided?}

Respondents indicated for which courses legal research skills instruction was provided by library staff.

$$
\begin{array}{ll}
\begin{array}{l}
\text { Number of institutions } \\
\text { with courses (2013) }
\end{array} & \text { Instruction Instruction } \\
\text { provided (2013) provided (2011) }
\end{array}
$$

$\begin{array}{llll}\text { Undergraduates } & 92 & 88(95 \%) & 94 \% \\ \text { Postgraduate professional } & 40 & 37(93 \%) & 85 \% \\ \text { Other taught postgraduate } & 86 & 80(86 \%) & 90 \% \\ \text { Research postgraduate } & 74 & 54(73 \%) & 70 \%\end{array}$

In most responding institutions, law library staff were involved in legal research skills instruction for all types of users. The proportion of institutions where library staff were involved in legal research skills instruction for undergraduates was slightly higher at $95 \%$, whilst there was an increase to $93 \%$ in the proportion involved in postgraduate vocational courses. Involvement with postgraduate taught courses decreased a few percentage points to $86 \%$ and involvement with training research postgraduates increased slightly to $73 \%$.

Except for the trend for training "other taught postgraduate students", all the other trends are encouraging.

\subsection{Integration with the teaching curriculum}

Respondents were asked in which courses was the library's contribution to legal research skills instruction timetabled and incorporated within the curriculum of study.

$$
\begin{array}{lll}
\text { Instruction } & \text { Instruction } & \text { Instruction } \\
\text { provided ('13) } & \text { integrated ('13) } & \text { integrated ('11) }
\end{array}
$$


Undergraduates

Postgraduate professional

Other taught postgraduate

Research postgraduate
88

37

80

54
$80(91 \%) \quad 87 \%$

$31(84 \%) \quad 81 \%$

$60(75 \%) \quad 70 \%$

$24(44 \%) \quad 38 \%$

The good news is that percentage levels of integration of the library's contribution have increased for all types of courses on the 2011 levels.

\subsection{How much teaching does a student receive?}

To understand how much training each of the courses noted above actually receive, respondents were then asked to note the number of timetabled contact hours of legal research skills instruction a student would receive from library staff over the duration of the whole course of study. Contact hours were defined as the length of time an individual student would spend receiving direct timetabled teaching or tutorial guidance.

For the 81 respondents $(2011: 85)$ who noted contact hours for undergraduates, hours ranged from 1 to 30 (2011: 1 to 14), with a mean of 5.1 hours (2011:5.4) and a median of 4 hours (2011: 5). Undergraduates in 37\% (2011: 48\%) of respondents' institutions received between 2 and 4 hours instruction from the law library staff.

34 respondents $(2011: 41)$ noted contact hours with library staff for students on the LPC, BVC, CPE, Institute of Legal Executives and other postgraduate professional courses. Hours ranged from 1 to 24 (2011: 1 to 8), with a mean of 3.1 hours (2011:3.5) and a median of 2 hours (2011: 3).

69 institutions (2011: 70) gave contact hours for other taught postgraduate students. These ranged from 1 hour to 15.25 hours (2011: 1 to 11 ), with a mean of 3.6 hours (2011: 4.1) and a median of 3 hours (2011: 3 ).

Finally, 42 respondents, comprising 30 old universities and 12 new universities (2011: 43 respondents with 32 old universities and 11 new) gave research postgraduates between 0.5 hours and 25 hours of legal research skills instruction (2011: 1 to 8.5 ), with a mean of 3.6 hours (2011: 3.1) and a median of 2 hours (2011: 2).

In general, the amount of teaching received by a research postgraduate has increased. However, decreases are noted for undergraduates, postgraduate vocational course students and taught course postgraduates (LLM).

\subsection{How many hours do librarians spend delivering legal research skills instruction?}

Respondents were asked to indicate the number of law library staff hours spent in delivering legal research skills instruction during the year. Preparation time was excluded. Eighty four institutions responded (2011: 89), with figures ranging from 0.5 hours to 300 hours (2011: 1.5 to 300$) .12$ respondents (2011: 17) spent under 10 hours teaching, 7 of whom were old universities and 3 new and 2 other institutions (2011: 12 old, 4 new, 1 other). At the other end of the scale, 11 respondents (2011: 5) of whom 7 were old universities and 4 new universities spent over 100 hours on instruction (2011: 3 old, 2 new, 0 other). The overall mean was 53 hours (2011: 37). The mean for old universities was 58 hours and new universities was 51 hours, and other institutions returned a mean of 6 hours (2011: old 39 hours, new 35 hours, other institutions 16 hours). The overall median was 30 hours (2011: 26).

On most measures librarians in both old and new universities appear to be spending more hours teaching than previously, and more of this teaching was being undertaken in old universities than in new universities. 


\subsection{Method of delivery}

Respondents were asked to indicate, for the instruction featured in section 14.2 above, which methods of delivery were used.

As in the five previous surveys, IT or database workshops were the most popular method of delivery, used by $86 \%$ of all respondents, $(2011: 81 \%)$. They were used most frequently for taught course postgraduate courses, where $72 \%$ of respondents used workshops, followed by undergraduate teaching with $71 \%$ of respondents using the method. Database workshops were used by $70 \%$ of respondents for their postgraduate professional courses and by $29 \%$ of respondents for research postgraduates.

Overall, large group lecture sessions were the next most popular method of delivery used by $83 \%$ of all respondents (2011: $75 \%$ ). They were most often used for undergraduate level teaching, where $76 \%$ of respondents used this method (2011: $63 \%$ ), followed by postgraduate professional courses with $50 \%$ of respondents (2011: $26 \%$ ), other postgraduate taught courses with $49 \%$ of respondents using this delivery method (2011: 49\%), and research students at $22 \%$ of respondents (2011: $20 \%)$.

One-to-one reference advice sessions were used by $74 \%$ of all respondents (new specific category offered on questionnaire). They were most often used for undergraduate level teaching, where $63 \%$ of respondents used this method, followed by other postgraduate taught courses with $59 \%$ of respondents, research students at $56 \%$ of respondents, and postgraduate professional courses with $45 \%$ of respondents using this delivery method.

Small group tutorial / seminar sessions based in a seminar room, rather than an IT room, were used by librarians in $40 \%$ of institutions (2011: $43 \%$ ). They were used most frequently for undergraduates by $31 \%$ of respondents (2009: $29 \%$ ), then taught postgraduates by $27 \%$ of respondents (2011: $20 \%$ ), and postgraduate professionals by $22.5 \%$ of respondents (2011: $15 \%)$. They were least often used for research postgraduate training, where the method was used in $18 \%$ of cases (2011: $16 \%$ ).

Locally produced online tutorials were used by $33 \%$ of responding institutions for legal research skills instruction (2011: $28 \%$ ). Online tutorials were used across all courses but especially with undergraduates, where $29 \%$ of respondents used this method of delivery (2011: $25 \%$ ) and taught postgraduate courses, with $25 \%$ of respondents (2011: $21 \%$ ). Eighteen percent of respondents used them with both postgraduate professional courses and research postgraduate courses (2011: $9 \%$ and $9 \%)$.

Student workbooks, which enable hands-on self-paced learning, were still used by just $20 \%$ of respondents (2011: 20\%). They were used by 10 institutions for postgraduate taught courses (2011: 6 institutions), by 9 institutions for postgraduate professional courses (2011: 8 institutions), by 7 institutions (2011: 13) for undergraduates and by 3 institutions with research postgraduates (2011: 1).

Four percent of respondents noted other methods. These included practical training in using print resources.

\subsection{Information literacy}

As in 2005, 2007, 2009 and 2011 we asked two survey questions specifically referring to the Association of College and Research Libraries' (ACRL) Competency Standards (American Library Association, 2000 - although currently under review) and the SCONUL Standards and the integration of these principles within the undergraduate law curriculum.

All 93 institutions responded (2011: 93), of which 46 or $49.5 \%$ did (2011: 30 or $32 \%)$. Of those institutions that did, 37 or $80 \%$ (2011: 25 or $83 \%$ ) embedded the principles within a law course whilst 9 or $20 \%$ (2011: 5 or $17 \%$ ) embedded them within a generic information literacy programme. 
These questions were first posed in 2005. The results for 2013 show an overall increase (compared with 2011) in the number of institutions integrating information literacy principles within the law undergraduate programme.

\section{Overseas links}

At the request of BIALL, questions were asked for the third time to explore whether institutions provided law courses overseas and, if so, the nature of the support the UK-based library and information service was required to provide to the overseas organisation and its students.

Of the 93 institutions which responded 20 or $21.5 \%$ (2011: 18 or $19 \%$ ) did provide law courses overseas, either by means of a partnership with an overseas institution or by franchise. They were 8 old universities (2011: 7) and 12 new universities (2011: 11). The courses offered by respondents were located in 19 countries (2011: 19): Malaysia (3 respondents), Belgium, Spain and Sri Lanka (2 respondents each), Albania, Cayman Islands, Cyprus, Czech Republic, Ethiopia, France, Greece, Guernsey, Hong Kong, Ireland, Japan, Netherlands, Singapore, Uzbekistan, Vietnam (South) (all one each).

None of the 20 institutions aimed their courses at pre-degree level (2011: 0). Thirteen focused on undergraduate courses (2011: 9) and 9 on postgraduate level courses (2011: 11) and 1 specifically at $\mathrm{PhD}$ level courses (2011: 0).

The most frequent type of support provided by library and information staff was providing email support for overseas registered students in finding resources (11 respondents. 2011: 10), technical assistance to overseas library and information staff (7 respondents. 2011: 7), providing access to new electronic resources (7 respondents. 2011: 4), creating lists of materials to be purchased by the overseas institution ( 6 respondents. 2011:3), setting up a subscription to new electronic materials (3 respondents. 2011: 5), and the purchase and shipping out of new print materials (2 respondents. 2011: 4).

Other forms of support included face-to-face teaching, "law librarian visited overseas to deliver training and provide workbooks", and providing access to existing electronic resources. Seven institutions provided no support at all (2011: 6).

\section{Other activities}

For the first time the survey questionnaire asked respondents about the contribution of their library staff to other law library activities such as creating web subject and research guides; providing content for law library web pages, social networking sites and web portals or gateways; and writing published articles. All 93 respondents answered the questions in this final section.

The following graph compares these five other activities undertaken by law library staff in old and new universities. 


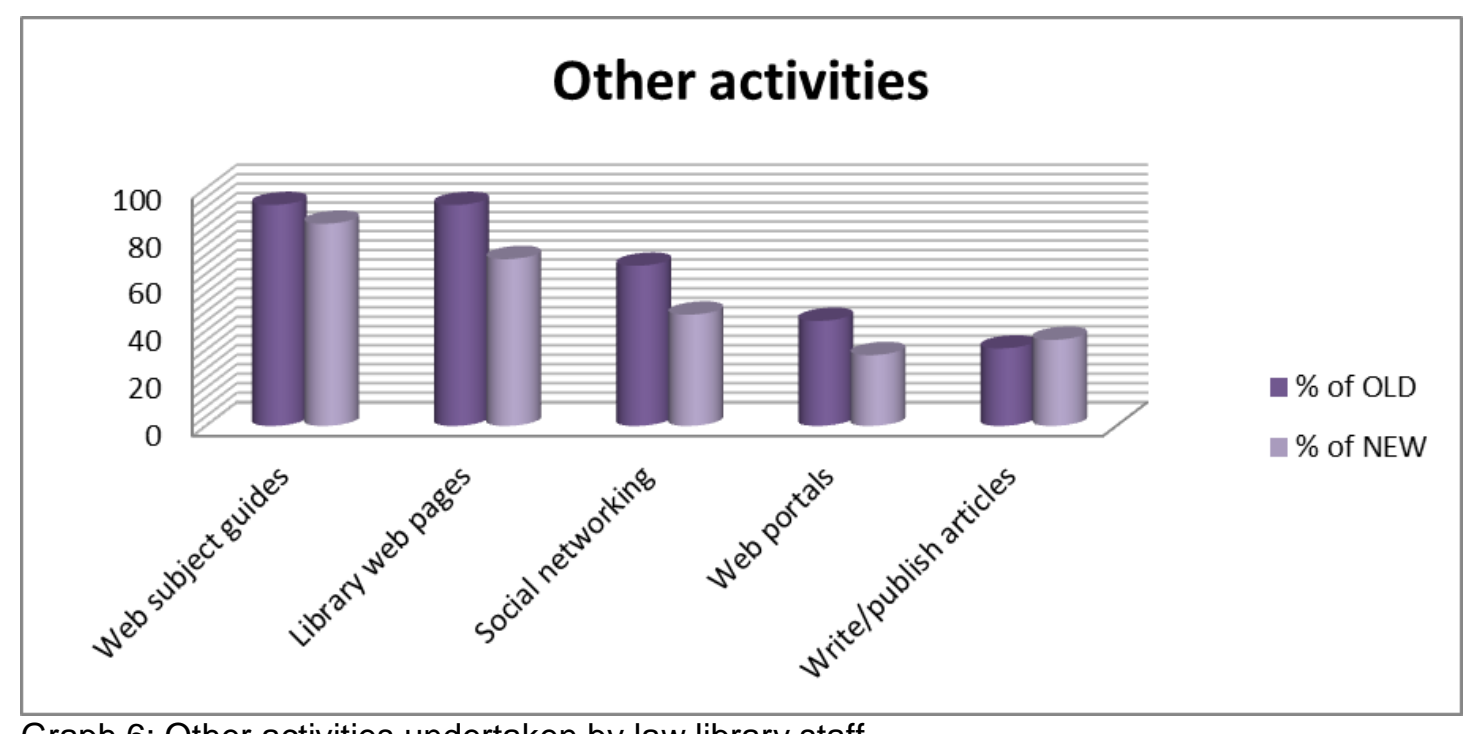

Graph 6: Other activities undertaken by law library staff

\subsection{Contribution to creating web subject and research guides}

In 83 libraries or $89 \%$ of respondents, law library staff created web subject and research guides. Of these 83 libraries, 40 were old universities or $93 \%$ of the total number of responding old universities. Forty were new universities or $85 \%$ of the total number of responding new universities, and 3 were other institutions or $100 \%$ of responding other institutions.

\subsection{Provide content for law library web pages}

In 74 libraries or $80 \%$ of respondents, law library staff provided content for their law library web pages. Of these 74 libraries, 40 were old universities or $93 \%$ of the total number of responding old universities. Thirty-three were new universities or $70 \%$ of the total number of responding new universities, and 1 was an "other" institution.

\subsection{Provide content for library social networking sites}

In 52 libraries or $56 \%$ of respondents, law library staff provided content for the library social networking sites. Of these 52 libraries, 29 were old universities or $67 \%$ of the total number of responding old universities. Twenty two were new universities or $47 \%$ of the total number of responding new universities, and 1 was an "other" institution.

\subsection{Provide content for web portals or gateways}

In 35 libraries or $38 \%$ of respondents, law library staff provided content for web portals or gateways. Of these 35 libraries, 19 were old universities or $44 \%$ of the total number of responding old universities. Fourteen were new universities or $30 \%$ of the total number of responding new universities, and 2 were "other" institutions.

\subsection{Write published articles}

In 31 libraries or $33 \%$ of respondents, law library staff wrote published articles. Of these 31 libraries, 14 were old universities or $33 \%$ of the total number of responding old universities and 17 were new universities or $36 \%$ of the total number of responding new universities. 
In summary, therefore, the most popular other activities in both old and new universities are firstly creating web subject and research guides, followed by providing content for law library web pages, providing content for social networking sites and providing content for web portals or gateways. Writing published articles is the least popular other activity.

Comparing other activities in old and new universities, it is more likely that law library staff will be contributing to web subject and research guides, law library web pages, social networking sites and web portals or gateways in old universities. On the other hand, it is more likely that law library staff will be writing published articles in new universities.

\section{Acknowledgements}

Firstly I must thank Dr Peter Clinch whose original survey template and previous high quality survey reports I have used in this report. Secondly as usual my job has been made considerably easier by having Laura Griffiths, an Assistant Librarian at IALS, to again fill the important administrative and statistical roles with her usual accuracy and efficiency. She has contributed significantly to the administration of the survey and helped me by calculating many of the statistics for the survey report.

\section{References}

Gee, David (2013) SLS/BIALL Academic Law Survey 2011/2012. Legal Information Management. 13(4), 260-277.

Gee, David (2012) SLS/BIALL Academic Law Survey 2010/2011. Legal Information Management. 12(3), 218-232.

Clinch, Peter (2011) SLS/BIALL Academic Law Library Survey 2009/2010. Legal Information Management 11(4), 272-288.

Society of Legal Scholars (2009) A library for the modern law school. A statement of standards for university law library provision in the United Kingdom - 2009 revision. Available at URL: http://www.legalscholars.ac.uk/documents/SLS-Library-for-a-Modern-Law-SchoolStatement-2009.pdf

\section{Appendix}

List of academic law libraries in the UK and Ireland that returned a completed 2012/2013 survey questionnaire

\begin{tabular}{|l|l|l|}
\hline Abertay University & Exeter University & Salford University \\
\hline Aberystwyth University & Gloucestershire University & $\begin{array}{l}\text { School of Oriental and African } \\
\text { Studies }\end{array}$ \\
\hline Anglia Ruskin University & Greenwich University & Sheffield Hallam University \\
\hline Aston University & Hertfordshire University & Sheffield University \\
\hline Bedfordshire University & Huddersfield University & $\begin{array}{l}\text { South Wales University (formerly } \\
\text { Glamorgan University) }\end{array}$ \\
\hline Birkbeck, University of London & Hull University & Southampton Solent University \\
\hline Birmingham City University & IALS (Institute of Advanced Legal Studies) & Southampton University \\
\hline Birmingham University & KCL (Kings College London) & $\begin{array}{l}\text { Squire Law Library (Cambridge } \\
\text { University) }\end{array}$ \\
\hline $\begin{array}{l}\text { Bodleian Law Library (Oxford } \\
\text { University) }\end{array}$ & Keele University & St Mary's University College \\
\hline
\end{tabular}




\begin{tabular}{|c|c|c|}
\hline Bolton University & Kent University & Staffordshire University \\
\hline Bournemouth University & Kingston University & Stirling University \\
\hline BPP University & Lancaster University & Strathclyde University \\
\hline Bradford College & Leeds Metropolitan University & Sunderland University \\
\hline Bradford University & Leicester University & Surrey University \\
\hline Brighton University & Limerick University & Sussex University \\
\hline Bristol University & Lincoln University & Swansea University \\
\hline Brunel University & Liverpool John Moores University & Teesside University \\
\hline Buckingham University & Liverpool University & Trinity College Dublin \\
\hline Canterbury Christ Church University & London South Bank University & UCC (University College Cork) \\
\hline Cardiff University & $\begin{array}{l}\text { LSE (London School of Economics and } \\
\text { Political Science) }\end{array}$ & UCL (University College London) \\
\hline Chester University & Manchester Metropolitan University & UEA (University of East Anglia) \\
\hline City University & Newcastle University & UEL (University of East London) \\
\hline Coventry University & Northampton University & Ulster University \\
\hline Cumbria University & Northumbria University & University of Central Lancashire \\
\hline De Montford University & Nottingham Trent University & University of Law \\
\hline Derby University & Nottingham University & $\begin{array}{l}\text { UWE (University of the West of } \\
\text { England) }\end{array}$ \\
\hline Dublin Business School & Oxford Brookes University & Warwick University \\
\hline Dundee University & Plymouth University & West London University \\
\hline Durham University & Portsmouth University & Westminster University \\
\hline Edge Hill University & Queen's University Belfast & Worcester College of Technology \\
\hline Essex University & Reading University & York University \\
\hline
\end{tabular}

\section{David Gee}

$7^{\text {th }}$ October 2014 